\title{
Klaus Peter Müller (ed.), Scotland 2014 and Beyond - Coming of Age and Loss of Innocence?
}

Frankfurt am Main, Peter Lang, 2015, 457 p.

\section{Silke Stroh}

\section{OpenEdition}

\section{Journals}

Electronic version

URL: http://journals.openedition.org/etudesecossaises/1141

DOI: 10.4000/etudesecossaises. 1141

ISSN: 1969-6337

\section{Publisher}

UGA Éditions/Université Grenoble Alpes

Printed version

Date of publication: 25 April 2016

Number of pages: 168-174

ISBN: 978-2-84310-324-7

ISSN: $1240-1439$

\section{Electronic reference}

Silke Stroh, "Klaus Peter Müller (ed.), Scotland 2014 and Beyond - Coming of Age and Loss of

Innocence?", Études écossaises [Online], 18 | 2016, Online since 01 January 2017, connection on 16

March 2021. URL: http://journals.openedition.org/etudesecossaises/1141 ; DOI: https://doi.org/

10.4000/etudesecossaises. 1141 
Alison Miller et à leur réappropriation d'un locus qu'avaient contribué à baliser James Kelman et Irvine Welsh à la fin du $\mathrm{xx}^{\mathrm{e}}$ siècle. Dans le chapitre deux, «Female crime fiction: the space of transgression», MarieOdile Pittin-Hédon se penche sur les romans de détection de Louise Welsh, Val McDermid et Denise Mina pour mettre en lumière les modalités d'inflexion par la voix féminine d'une littérature écossaise de genre (policier et gothique) déterminée à ne pas se laisser fossiliser. Les chapitres suivants sont consacrés à l'entreprise de dés-invention puis réinvention du passé et du territoire écossais (James Robertson), à la représentation du multiculturalisme, des questions linguistiques qui en découlent (Suhayl Saadi) et au traitement en littérature de l'entrée de l'Écosse dans le marché mondialisé (Ewan Morrison). Nourri de ces considérations, le dernier chapitre «The confines of the Human» explore le traitement du «cosmopolitisme» depuis la dialectique individu-collectivité dans les nouvelles de Michel Faber, Des Dillon, Suhayl Saadi, Dilys Rose et bien d'autres.

The Space of Fiction propose une réflexion approfondie et actualisée des littératures écossaises du Xxi siècle. Dans cet ouvrage qui ne tardera pas à devenir de référence, Marie-Odile Pittin-Hédon fait la démonstration du dynamisme d'une nouvelle scène littéraire écossaise attachée à travailler l'élasticité de l'écart entre des problématiques dites «nationales» (si tant est qu'elles puissent n'être que cela) et celles qui débordent les seules frontières de l'Écosse.

Silke Stroh

University of Muenster

Klaus Peter Müller (ed.), Scotland 2014 and Beyond - Coming of Age and Loss of Innocence?, Frankfurt am Main, Peter Lang, 2015, 457 p.

Structured around the central nexus of the Scottish independence referendum of 18 September 2014, this interdisciplinary volume investigates a wide range of cultural and social issues which have pertained to the independence debate, and to the wider developments that led up to it. As the word "beyond" in the book title indicates, the collection also discusses prospects for the country's post-referendum future. Although the referendum result turned out a 55-percent vote in favour of staying within the UK, it soon became clear that Scottish nationalism and the demand for 
constitutional and social change are by no means off the agenda, even if they remain, for the present, consigned to an intra-British arena. Hence, many of the issues which animated the referendum debate are bound to remain highly topical for quite some time, and this collection of essays is of continuing importance. Its origins lie in a conference that took place in the year before the referendum, in October 2013. Its theme, similar to the book's title, was 'Scotland 2014: Coming of Age and Loss of Innocence?"; the venue was the Germersheim campus of Mainz University (Germany). About two thirds of the conference papers found their way into this book. They have been revised and updated for publication, although most of those updates seem to have taken place before the referendum, earlier in 2014, so that various chapters' remarks on the postreferendum future remain prognoses, not yet including hard facts on the vote's outcome or the subsequent political developments between midSeptember 2014 and the book's publication in February 2015.

To some extent, such a time lag may have been hard to avoid, given the usual production time for academic books between manuscript submission and actual publication. Nonetheless, if pre-referendum publication really was unfeasible, it may have been preferable to wait a few more months in order to give authors the time to at least delete such obviously "dated" phrases as "the likely outcome of the September ballot" (p. 61), and perhaps even to insert a few more substantial updates on the first post-referendum events. For instance, such a delay may have given some authors the chance to modify their speculations on Scotland's future now that the much-anticipated "no" vote has moved from likelihood to reality, whereas the likewise much-anticipated decline of the Scottish National Party following such a "no" vote has not become a reality. One chapter's pre-referendum speculation that a "no" vote would be "snuffing out [...] the flame" around which SNP supporters had rallied, and that this might mean a "traumatic" future for the party (p. 158), strikes us as odd if we read it in the knowledge that the SNP experienced a spectacular rise in membership immediately after the referendum, quickly regrouped under new leadership, and seemed to enjoy a steady rise in popularity during the months which led up to the book's publication.

That said, it is also striking how much of the volume's content does in fact not seem anachronistic, and instead still seems just as relevant for 2015 and beyond. This not only pertains to the obviously still valid analyses of the socio-cultural developments before 2014 which laid the foundations for the referendum debates, or which illuminate other aspects of the complex relationship between Scotland and England, of Scotland's position within the UK, and of its relationship with other countries. Many of the book's statements on Scotland's future likewise remain relevant, 
either because various prognoses seem to have come true (and the contributors' reasons for their predictions appear to be plausible explanations), or because various social questions of the pre-referendum era remain unanswered and will continue to be debated as part of intra-British reform agendas and ongoing pro-independence discourse.

Besides the publication date, another aspect which might raise questions is the subtitle: at first sight, it might suggest a problematic reproduction of condescending, quasi-colonial tropes of non-independent Scotland as immature, childlike, or naïve, as opposed to a more mature, politically hard-headed, and realistic Union-British parent state (dominated by England, which has historically often been portrayed in the same mature and parental role as the Union-British state as a whole). However, the echoing of those images in this volume's sub-title is best seen as ironic, as those discursive traditions are actually expressly criticised within the book. Far from seeming immature or unrealistic, Scottish political and socio-cultural debates are shown to be highly pertinent to discussions on how to change social realities for the better and to create more equitable, democratic, and sustainable futures, both within Britain and on an international level.

Contributions comprise an impressive spectrum of academic disciplines - including anglophone Literary and Cultural Studies, Film Studies, Media Studies, History, Political and Social Science, and Law-as well as expertise from other professional sectors such as the media or civil service. The collection opens with two general introductory chapters by the editor, Klaus Peter Müller, the first being an outline of the book's rationale, thematic scope, and structure, while the second sets the Scottish debate on identity, autonomy, popular sovereignty, and social justice within wider British, European, and global contexts. This second chapter also contains some very helpful post-referendum updates. Subsequent chapters of the volume are divided into five sections. Section I, "History and Politics", begins with a contribution by Dauvit Brown which examines the relationship between Scottish and British statehood (and identity) through the lens of medieval history and modern international law. Subsequently, Catriona Macdonald charts the complex relationship between Scottish nationalism and unionism in the perspectives of politicians, historians, writers, and artists from the nineteenth century to the present, and stresses the difficulty of drawing straightforward historical lessons for the current debate. Murray Pittock draws on theories of nationalism and on Trauma Studies in order to demonstrate how constructions of Britishness as a national community repressed memories of internal conflict, and of different patriotisms oriented more towards Scotland and the UK's other constituent nations. Failure to openly confront the problems 
of Britishness, and the imperfect reconciliation of dissonant experiences, are identified as important factors in current debates.

Section II, "The Media", is opened by Neil Blain, who analyses how an anglocentric and unionist bias in the news media, along with failures in Scotland's own educational and academic sector, perpetuate negative images of Scotland and its people. He also shows how this has impacted on the independence debate, specifically with regard to the "Project Fear" strategies of the "no" campaign which persistently stressed the risks of independence and the limits of Scottish potential. Further instances of media bias, but also examples of more balanced reporting, are identified by David Hutchison's case study of TV and newspaper coverage of the Scottish government's White Paper on independence. A different medium, i.e. film, is the focus of David Martin-Jones's chapter. He analyses representations of Scotland which question the primary importance of the nation-state, favouring the smaller scale of intensely localised affiliation (e.g. by stressing Scotland's internal cultural diversity) or the larger scale of transnational connections, for instance in terms of class or diasporic affiliations. These other frameworks might help to explain why strong Scottish identifications do not always translate into support for independence. Nonetheless, the author also asks whether a Scottish nation-state might be seen as a valid platform to negotiate those transnational issues, for instance to counteract certain negative effects of neo-liberal global capitalism. Peter Jones's essay proceeds from Neil MacCormick's distinction between two kinds of nationalism, an "existential" one based on notions of a distinct essential identity that in itself is already sufficient to justify independent statehood, and a "utilitarian" one where support for independence depends on whether it promises sufficient practical advantages. Drawing on empirical data, for instance from social attitudes surveys, Jones analyses the proportion of "existential" and "utilitarian" elements in the Scottish populace's approach to Scottish and British nationhood, and discusses how these correlate with referendum voting. Miriam Schröder also deals with Scottish identities and self-perceptions. She discusses examples of how the nation has been narrated, in both negative and positive terms, and examines the implications of these narratives for Scottish-English relations, attitudes on unionism and nationalism, national confidence and national futures.

In section III, "The Law and the Constitution", William Elliot Bulmer charts differences between the constitutional traditions of Scotland and Westminster, for instance concerning the former's emphasis on popular sovereignty. He traces the emergence of a modern Scottish constitutional tradition since the 1960s, showing how it has been shaped by earlier Scottish traditions and by modern international influences, especially from 
the Nordic states, but also from other European countries, non-European Commonwealth states, and international human rights standards. At the same time, he identifies lingering influences from the Westminster model. This is complemented by Aileen McHarg's case study of the specific role of referendums in changing the British constitutional tradition. Again stressing different perceptions of sovereignty (e.g. popular vs parliamentary), she also identifies three different perceptions of the British state and its territory: firstly, as a "unitary state" which, at least at first sight, foregrounds the primacy of the Westminster Parliament's rights over Holyrood's; secondly, as a "union state" where sovereignty primarily lies with the Union's constituent nations; and thirdly, as a "quasi-federal state" based on shared sovereignty. She also analyses the role of these different models in debates about the 2014 referendum, and in Britain's future.

Section IV is concerned with "Scotland, Scottish Society, and Independence in Literature and Literary Studies". Gerard Carruthers's case study focuses on the reception of Robert Burns and on the initiatives which led to the establishment of the Chair of Scottish History and Literature at Glasgow University in 1913. He relates this to a wider trend in Scottish literary criticism to produce ahistorical, essentialist, anglocentric, pessimistic, politically over-determined, and simplistic readings of Scottish literature. He argues that more carefully historicised readings can promote not only a more complex, but also a more positive perspective on Scottish culture. Valentina Bold's chapter discusses James Hogg's The Brownie of Bodsbeck (1818). Set in the Covenanting period of the seventeenth century, it offers a strongly regional, localised take on national identity and on the violence of former intra-national conflicts. Bold also suggests that it offers lessons (e.g. on self-assertion and morality) for the nation during Hogg's own time - and in ours. This localist emphasis is complemented by Ian Duncan's chapter, which focuses more on international dimensions, relating Hogg's contemporary Walter Scott to the emergence of a concept of "world literature". However, Scott's international dimension does not necessarily imply an excessive endorsement of universalist norms; instead, there is also considerable emphasis on difference, plurality, and alternative possibilities. Ian Campbell charts how various Scottish fiction writers have used "double vision" as a narrative strategy which gives the reader superior insight that transcends the more limited perspective of the characters. Used by John Galt, J. M. Barrie, Lewis Grassic Gibbon and others, this strategy has great potential for irony, satire, the charting of social change, and analytical reflection. This is also pertinent to the contemporary literary scene and its relationship to the independence debate. Margery Palmer McCulloch surveys the relationship between modern Scottish writers and their country's "coming 
of age", in both cultural and political terms, and with regard to local, national, as well as international frameworks. While placing special emphasis on the period between the two World Wars, she also traces later developments, right up to Scott Hames's 2012 collection Unstated: Writers on Scottish Independence. The final chapter of this section focuses on literary and cultural theory, as Kirsten Sandrock discusses the uses and abuses of postcolonial perspectives in Scottish Studies in general and the independence debate in particular.

Section V of the volume is entitled "Participation, Ethnic, and Sociological Views on Scotland: Engaged in the Creation of a New Scotland?". Eberhard Bort focuses on the need to increase local democracy in Scotland, at a sub-national level, an issue which has not been sufficiently addressed since devolution, neither by Westminster nor by Holyrood, and neither by unionists nor by the SNP. The seriousness of Scotland's local democracy deficit is highlighted by comparative data on other European countries. Unitary constructions of nationhood can also create other problems, as Bashabi Fraser reminds us: such constructions often hinder the development of a progressive, flexible, pluralist and inclusive kind of national identity which is able to accommodate ethnic diversity. Fraser ponders these issues through the lens of her own positionality as a "New Scot" and a member of the South Asian diaspora, but also considers wider aspects of the complexities of belonging between local, national and transnational affiliations. She highlights the chances offered by a more inclusive concept of Scottishness and discusses cultural, educational and political strategies which might help to promote it. Personal positionality features even more strongly in Deirdre Forsyth's essay "Why I am Voting Yes", where she reflects on the ways in which her background, her family's involvement in Scottish politics, and her own experience of Scottish culture have shaped her political views. She also identifies various key areas of contemporary policy where independence could make a positive difference. Zooming in on one particular policy area, namely social welfare, Gill Scott and Gerry Mooney's chapter charts how devolution and the independence debate have become intertwined with discussions on social justice and the future of the welfare state - in Scotland and beyond. Roland Sturm's chapter likewise stresses that the relevance of Scottish debates does not stop at Scotland's borders. He discusses the role of Scotland as a "catalyst for constitutional change" across Britain as a whole. Sturm also considers future implications of the concepts of "devolution max" and "asymmetrical federalism", as well as the problem of England's position regarding devolution and independence.

Well structured, well laid out, and easy to navigate, with abstracts prefaced to each chapter, a helpful index, and a very wide thematic and 
disciplinary range, this volume is a highly useful compendium to various aspects of Scottish nationhood, its relationship to Britishness, devolution, the continuing independence debate, and its relevance to wider international discussions on regionalism, secession and social justice.

\section{Cyril Besson}

Université Grenoble Alpes

Sarah Dunningan and Suzanne Gilbert (eds), The Edinburgh Companion to Scottish Traditional Literatures, Edinburgh, Edinburgh University Press, 2013, 216 p.

"Traditional literatures" is a rather elusive concept that has always been confronted to an intractable problem of definition. Because it comes into sharp contrast with printed literature and its "fixed" objects, the notion is confronted to instability at every step, from initial performance, through intergenerational transmission, to ultimate cultural relevance, making the concept a particularly slippery one, so much so that subsuming such varied components (ballad, romance, folk song...) under one label may at times seem futile. Attempts at a rationalization of the phenomenon are often unconvincing, as the purported reductionism of well-meaning authors tends to oversimplify and exclude the "genre's" infinite variety, leading to a vision of things that, for being consistent, cannot but be incomplete. This is especially true when the sort of taxonomy emerges under specialists' pens that in the end identifies nothing but its own intrinsic prejudices.

The editors of The Edinburgh Companion to Scottish Traditional Literatures have wisely decided to tackle the subject without resorting to excessive categorizing or theorizing, as their clear, precise, and thought-provoking introduction establishes, although this is no indication that every contributor shies away from classification, as can be seen in the volume's second chapter ("Genre"). The frustration with this approach is that a suspicion of nominalism may loom over the brand, "traditional literatures", especially since historical record of the many variants of one ballad (all the more so its origins, and the phenomenon as a whole) is frequently spotty, leaving an impression that the researcher is fated, Danaides-like, to strive vainly for the bottom of things. This could have led the volume to indulge in the ambiguous pleasures of micro-history, with all the pit- 